\title{
Situated Game Teaching Through Setplays: An Innovative Model to Teach Sports in Physical Education
}

\section{Oyun Senaryolarıyla Durumsal Öğretim: Beden Eğitimi Derslerinde Spor Öğretimi için Yenilikçi Bir Model}

Fatih Dervent $^{\mathbf{1}}$ (iD) https://orcid.org/0000-0002-2612-3549

Faculty of Sport Sciences, Marmara University, Istanbul, Turkey

Erhan Devrilmez iD https://orcid.org/0000-0002-5136-7510

School of Physical Education and Sports, Karamanoğlu Mehmet University, Karaman, Turkey

Xiuye Xie $\quad$ (iD) https://orcid.org/0000-0001-5751-1272

Department of Human Performance and Health Education, Western Michigan University, Kalamazoo, MI. USA

Weidong Li $\quad$ iD https://orcid.org/0000-0002-0838-4120

Department of Human Sciences, The Ohio State University, Columbus, OH. USA.

\begin{abstract}
Physical education teachers are expected to have sport specific content knowledge and know pedagogical models in order to teach sports and games in physical education lessons in authentic settings. Even though sports in physical education lessons are taught sufficiently, teaching sport specific skills mostly depends on traditional or techniques-focused teaching methods. The purpose of this study was to explain components, qualities and pedagogical steps of an innovative pedagogical model, Situated Game Teaching through Set Plays, which uses situated game scenarios reflecting real match situations, and discussing its appropriateness for physical education and sport curriculum in Turkey. The aim of this model is to improve students' game competencies through situated game scenarios and support them to enjoy a lifelong physical activity for a healthy life. Students who are mentally engaged to analyze the cues and relations among game parameters can improve reflective thinking, decision making and problem-solving competencies to select appropriate techniques, strategies and tactics. Future research
\end{abstract}

\footnotetext{
${ }^{1}$ Corresponding author: Fatih Dervent

Marmara Üniversitesi, Spor Bilimleri Fakültesi, Anadoluhisarı Yerleşkesi, Beykoz, İstanbul, Türkiye. fatih.dervent@marmara.edu.tr
} 
should focus on analyzing the effectiveness of the model on technique development, tactical decision making, and motivation of students.

Keywords: Sports, pedagogical model, situated learning, game scenarios

\section{Öz}

Beden eğitimi öğretmenlerinin, ögretim sürecini gerçek koşullara uyumlu hale getirmek için öğrettikleri spor ve oyunlara ait alan bilgisine sahip olmalarını yanında pedagojik modelleri bilmeleri ve uygulamaları beklenmektedir. Beden eğitimi derslerinde spor dalları yeterince öğretiliyor olsa da spora özgü becerilerin öğretimi çoğunlukla geleneksel ya da teknik odaklı ögretim yöntemleriyle gerçekleştirilmektedir. Bu çalışmanın amacı temelini durumsal öğrenme kuramından alarak hazırlanan yenilikçi bir pedagojik model olan Oyun Senaryolarıla Durumsal Öğrenme Modelinin bileşenleri, özellikleri ve pedagojik adımlarını açıllamak ve Türkiye beden eğitimi ve spor dersi öğretim programlarına uygunluğunu tartışmaktı. Modelin hedefi ilişkisel ve durumsal oyun senaryoları yoluyla öğrencilerin oyunsal yeterliliklerini geliştirmek ve onları yaşam boyu sağlık kazandırıı fiziksel aktiviteden keyif almaları konusunda desteklemektir. Modelin, ipuçlarını kavramak ve bunlar arasındaki ilişkileri analiz etmek için zihinsel çaba harcayan öğrencilerin maç koşullarında uygun teknik, strateji ve taktiği seçmek için yansıııcı düşünme, karar verme ve problem çözme konusundaki yetkinliklerini geliştirme potansiyeli olduğu düşünülmektedir. Gelecek çalışmaların modelin öğrencilerin teknik gelişimi, taktiksel karar verme ve güdülenmeleri üzerindeki etkisini incelemesi önerilmektedir.

Anahtar kelimeler: Spor, pedagojik model, durumsal öğrenme, oyun senaryoları

\section{Giriş}

Spor dallarının öğretimi beden eğitimi ders programlarının özünü oluşturmaktadır. Beden eğitimi öğretmenleri öğrencileri katılıma teşvik eden ilgi çekici özellikleriyle farklı spor dalları ve oyunlara özgü hareket örüntülerinin öğretimine yıllık planlarında büyük ölçüde yer verirler. Türkiye'de 5-8. sınıflar için hazırlanan beden eğitimi ve spor dersi öğretim programının ilk üç çıktısı incelendiğinde, sporun beden eğitimi ve spor dersi öğretim programının temel amaçlarına ulaşmadaki önemi kolayca anlaşılmaktadır. Beden eğitimi ve spor dersini alan öğrencilerin (1) çeşitli fiziksel etkinliklere ve sporlara özgü hareket becerilerini geliştirmesi, (2) hareket kavramlarını ve ilkelerini, çeşitli fiziksel etkinliklerde ve sporlarda kullanması ve (3) hareket stratejilerini ve taktiklerini, çeşitli fiziksel etkinliklerde ve sporlarda kullanması beklenmektedir (Milli Eğitim Bakanlığı [MEB], 2018, s.9).

Kaliteli beden eğitimi programlarının yapı taşlarını tanımlamaya çalışan kuruluşlardan biri olan Birleşmiş Milletler Eğitim, Bilim ve Kültür Kurumu (United Nations Educational, Scientific, Cultural Organization [UNESCO]) fiziksel aktivite ve sporun aktif ve sağlıklı yaşam için intiyaç duyulan devinişsel, bilişsel, sosyal ve duygusal becerilerin edinilmesinin temelini oluşturduğunu belirtmektedir (UNESCO, 2015). Uluslararası Yükseköğretimde Beden Eğitimi Birliği (International Association for Physical Education in Higher Education [AIESEP]), beden eğitimi öğretmen yetiştirme programları üzerine yayınladığı durum değerlendirme raporunda, beden eğitimi dersinin odağında çocuk ve gençleri aktif yaşam tarzına yönlendiren, onların duygusal, sosyal ve fiziksel sağlıklarını destekleyen fiziksel aktivite ve sporun olması gerektiğinin altını çizmektedir (AIESEP, 2014). Sporun beden eğitimi program içeriklerine dahil edilmesinin önemi, Amerika Sağlık ve Beden Eğitimciler Topluluğunca (Society of Health and Physical Educators America [SHAPE America], 2014) okul öncesinden 12. sınıfa kadar her bir sınıf düzeyi için belirlenen öğrenme çıktıları ve beden eğitimi ders programı standartlarında, yine aynı şekilde Uluslararası Bakaloryanın (International Baccalaureate, 2014) sağlık ve beden eğitimi program yeterliliklerinde vurgulanmaktadır. Türkiye'de spor dalları beden eğitimi derslerinde yeterince öğretiliyor olsa da spora özgü becerilerin öğretimi çoğunlukla 
geleneksel ya da teknik odaklı öğretim yöntemleriyle gerçekleştirilmektedir (Ince \& Hunuk, 2010). Bu öğretim yaklaşımında izole ortamlardaki teknik öğretimi dersin büyük bir bölümünü kapsamakta, oyun oynamaya ise yeterli zaman ayrımamaktadır. Oyun oynandığı anlarda bile öğrenilen tekniklerin o sporun oynandığı gerçek maç koşullarında nasıl kullanılabileceğine yönelik bağlantılar kurulmamaktadır (Kirk \& MacPhail, 2002). Oysa ki çağdaş öğretim uygulamaları oyunları kendi bağlamında öğretmenin önemine vurgu yapar (Harvey \& van der Mars, 2010). Beden eğitimi öğretmenleri, öğretim sürecini gerçek koşullara uyumlu hale getirmek için öğrettikleri spora ait alan bilgisine sahip olmalarının yanında pedagojik modelleri bilmeleri ve uygulamaları beklenmektedir (Ward, Piltz \& Lehwald, 2018). Öğretimi gerçek koşullara yakınlaştırmak ile kastedilen öğretim tasarımlarını öğretilen sporun doğasına mümkün olduğunca benzer hale getirmektir. Bu benzerlik öğrencilere sunulan öğrenme fırsatlarının bir başka deyişle ders kalitesinin artmış olduğuna işaret eder (Kirk \& MacPhail, 2002).

Bu bağlamda, sporu ve uyarlanmış oyunları temel öğretim içeriği olarak kullanarak, öğretimi gerçeğe uygun başka bir ifadeyle otantik koşullara taşıan beden eğitimi öğretimine özgü çeşitli öğretim modelleri geliştirilmiştir. Bunlar arasında Spor Eğitim Modeli (Siedentop, Hastie \& van der Mars, 2011), Taktik Oyun Modeli (Mitchell, Oslin, \& Griffin, 2013), Taktik Oyun Yaklaşımı (TOYA) (Bunker \& Thorpe, 1982), Oyun Uygulamaları (Launder \& Piltz, 2013), ve Kısıtlama Yaklaşımı (Renshaw, Davids, \& Savelsberg, 2010) sayılabilir. Beden eğitimine özgü öğretim modellerinin en güncellerinden biri de Oyun Senaryolarıla Durumsal Öğretim Modelidir (Li, Xie \& Xi, 2018). Rink'e (1999) göre öğretim modelleri köklerini bir öğrenme kuramından almalıdır. Oyun Senaryolarıyla Durumsal Öğretim Modelinin güçlü yanlarından birisi temelinin durumsal öğrenme kuramına dayanıyor olmasıdır. Bu model, durumsal öğrenme kuramının ortaya koyduğu ilişkisel, durumsal, otantik ve sosyal bakış açısının öğretmenlere spor dallarının öğretimi için uygulanabilir, anlamlı bir yol sunduğu varsayımında bulunur (Li, Xie \& Li, 2018).

Durumsal öğrenme kuramı, bilgi ve öğrenmenin oluşumunu yapılandırmacı yaklaşım perspektifinden açıklar (Kirk \& Macdonald, 1998). Buna göre öğrenme, sosyal ve kültürel olarak yapılandırılmış bilgi, biliş, anlam, etkinlik gibi öğelerin birbirine bağlı ve sosyal ilişkisini ifade eden dinamik bir süreçtir. Sosyal dünyanın merkezindeki birey yeni dahil olduğu öğrenme topluluklarında çevresel katıımdan adım adım tam katııma eriştiği bir süreci yaşar. Bu dinamik süreç yenilerle önceki katıımcılar arasında ortak uygulama, paylaşım ve ilişkilerin değişimini içeren sosyal bir dönüşüm yaratır (Lave \& Wenger. 1991).

Lave ve Wenger (1991, s.55) durumsal öğrenme kuramında meşru çevresel katıım ve öğrenme toplulukları olarak niteledikleri iki anahtar kavram kullanmışlardır. Meşru çevresel katılım, bilgili ve becerili kişiler ile öğrenme topluluklarının oluşturulmasında ortaya çıkan sosyal ilişkiler arasındaki "kavramsal köprüdür". Lave ve Wenger (1991) meşru katılımı bireyin sadece sosyal dünyadaki öğrenme sürecine dahil olması değil aynı zamanda öğrenme içeriğinin bir öğesi olması olarak ifade eder. Birey sosyal dünyada çoklu, değişken, ya da kapsayıcı roller alabilir. Bireyin sosyal uygulamalara artan katıımı, bilgi kaynaklarına erişimini, adım adım öğrenme hedefini yapılandırmasını ve öğrenme topluluklarında kimlik oluşturmasını sağlar (Li, Xie \& Li, 2018). Çevresel katılımdan tam katılıma uzanan süreçte bireylerin sorumluluk ve çabaları gittikçe artarken kendilerinden talep edilen görevler daha zor ve karmaşık hale gelir (Lave \& Wenger, 1991).

Öğrenme toplulukları üyelerin bilgi ve beceri kazanımlarını arttırmak için birlikte çalıştıkları çevreyi kapsar (Anderson, Reder \& Simon, 1996). Öğrenme toplulukları farklı üyelerin çok çeşitli ilgilerini, bakış açılarını, öğrenme etkinliğine farkı katılım düzeyleri ve katkılarını, kültürel geçmişlerini içerir (Hunuk, Ince \& Tannehill, 2013; Lave \& Wenger, 1991). Öğrenilen şeyler öğrenildiği duruma özgüdür (Greeno, 
Smith \& Moore, 1992). Dolayısıyla öğrenme toplulukları bireysel katılımların toplamından daha fazlasını ifade eder.

Beden eğitimi dersinde öğrencilerin çeşitli fiziksel etkinliklere ve sporlara özgü hareket becerilerini, kavram ve ilkelerini, strateji ve taktikleri öğrenmek, aktif ve sağlıklı yaşam, sosyal ve düşünme becerilerini kazanmak için dahil olduğu (MEB, 2018) öğrenme topluluğu olarak değerlendirilebilir. Okul içinde sınıflar, sınıfların içinde gruplar ve takımlar olmak üzere birbirleriyle örtüşen birçok farklı öğrenme topluluğu okul beden eğitimini oluşturur (Kirk \& Macdonald, 1998). Beden eğitimi derslerindeki spor dallarının öğretimi sadece teknik, taktik, strateji, oyun kuralları, görgü kuralları, güvenlik kurallarını içermekle kalmaz. Bunların yanında beden eğitimi öğretmenlerinin sahip olduğu felsefe, öğretim stili, kullandığı öğretim modellerini, öğrencilerin ilgi, istek, değer, yetenek, bilgi düzeyleri, önceki öğrenmeleri ve deneyimlerini ayrıca okulun bulunduğu sosyo-ekonomik çevre, imkanlar, diğer öğretmen ve yöneticilerin tutumu gibi birçok öğenin etkileşimiyle oluşan öğrenme topluluklarında gerçekleşir.

Öğrenciler, meşru çevresel katıımdan tam katııma giden dinamik ve sosyal süreçte spor dalına özgü oyun yetkinliklerini geliştirirler. Öğrenme, öğrencilerin bu dinamik sürece aktif katılımı ve onlarla öğrenme görevleri ve çevre arasında yaşanan ilişkiler sonucu oluşur ( $\mathrm{Li}, \mathrm{Xie} \& \mathrm{Li}$, 2018). Beden eğitimi öğretmeninin kolaydan zora basitten karmaşığa basamaklayarak tasarladığı etkinlikler, öğrencilerin katıldığı öğrenme görevlerinde adım adım gelişmelerine fırsat verir. Öğrencilerin okulda farklı konu alanlarında edindikleri bilgi ve beceriler, okul dışındaki öğrenme topluluklarında da kullanabilecekleri zengin içeriği yansıtmalıdır. Rovegno'ya (2006) göre bunu sağlayabilmenin yolu ders içeriklerini birey, etkinlik ve çevre arasındaki ilişkisel bakış açısını dikkate alarak otantik şekilde tasarlamaktır.

Kirk ve MacPhail (1998) taktik oyun yaklaşımının bağdaştırıcı bazı adımlarının durumsal ve ilişkisel öğelerinin durumsal öğrenme kuramına vurgu yaptığını belirtmiş̧tir. Spor eğitim modeli de durumsal öğrenme kuramının kültürel ve geleneksel bakış açısını yansıtmak için önemli bir güce sahiptir (Kirk, Brooker \& Braiuka, 2000). Şöyle ki takım üyeliği, sonuç etkinliği ve festival gibi sporun kültürel yapısını içeren öğeleri öğrencilere okul tabanlı öğrenme topluluklarında meşru çevresel katılım fırsatı sunarak öğrenmelerini destekleyebilir. Çünkü, spor eğitim modeli sporun gerçek yaşamdakine oldukça benzer halini beden eğitimine taşır. Bu durum öğrencilerin derslerde yaşadığı otantik deneyimleri okul dışındaki uygulamalarla ilişkilendirmesine imkan verebilir. Takım üyeliği için üstlendiği roller de farklı sorumluluklar alabilmesine destek olur (Kirk \& Kinchin, 2003). Spor eğitim modelinin sporun kültürel boyutunu yansıtmak için önemli bir potansiyeli olduğu öne sürülmüş olsa da öğrencilerin bu şekilde düşündüklerine yönelik bir araştırma bulgusuna rastlanmamıştır (Kirk, Brooker \& Braiuka, 2000). Araştırmacılar durumsal öğrenme kuramını taktik oyun yaklaşımı ve spor eğitim modeli ile iliş̧kilendirmiş olsalar da kuram bugüne dek bir öğretim modelinin kavramsal çerçevesi olarak kullanılmamıştır (Harvey, Pill \& Almond, 2018). Oyun Senaryolarıyla Durumsal Öğrenme Modeli ise durumsal öğrenme kuramını kavramsal çerçeve olarak kullanarak hazırlanmış yenilikçi bir öğretim modelidir. Bu çalışmanın amacı gerçek maç koşullarını yansıtan durumsal oyun senaryolarının beden eğitimi derslerinde kullanımına yönelik olarak Oyun Senaryolarıyla Durumsal Öğrenme Modelinin (Li, Xie \& Li 2018) bileşenleri, özellikleri ve pedagojik adımlarını açıklamak ve Türkiye beden eğitimi ve spor dersi öğretim programlarına uygunluğunu tartışmaktır.

\section{Modelin Bileşenleri}

Oyun Senaryolarıyla Durumsal Öğretim Modelinin hedefi ilişkisel ve durumsal oyun senaryoları yoluyla öğrencilerin oyunsal yeterliliklerini gelişstirmek ve onları yaşam boyu sağlık kazandırıcı fiziksel 
aktiviteden keyif almaları konusunda desteklemektir (Li, Xie \& Li, 2018). Bu bölümde Oyun Senaryolarıyla Durumsal Öğretim Modelinin temel bileşenleri açıklanmaya çalışılmıştır.

Durumsal oyun senaryoları. Durumsal oyun senaryoları kurallar, oyuncuların pozisyonları, boş alanlar, teknik, strateji ve taktikler gibi oyunun ana öğeleri arasında önceden belirlenmiş ilişkilerin eylem planı olarak ifade edilebilir ( Li, Xie \& Li 2018). Bu modelde teknik ve taktikler, kavramsal olarak öğrencilerin gelişim düzeylerini temel alarak ayrıntılı şekilde planlanır. Teknik ve taktikler, oyunun diğer değişkenleriyle tam anlamıla bütünleştirilmiş olarak durumsal oyun senaryolarıyla öğretilir. Dolayısıyla beceriler birbirinden soyutlanmış değil bütüncül ve ilişkilendirilerek öğretilir (Bereiter, 1990). Her bir durumsal oyun senaryosu, öğrencilerin gelişim seviyelerine özgü bir şekilde gerçek maç koşullarını yansıtmaktadır. Sporları otantik öğrenme ortamlarında anlamını kaybetmeden öğrenen öğrenciler, öğrendikleri becerileri okul dışındaki sportif ve rekreasyonel etkinliklerde de uygulayabilirler (Li, Xie \& Li 2018).

Öğretilen sporun farklı bileşenleri arasındaki ilişkinin incelenmesini ve buna göre karar almayı içeren oyun senaryoları, beden eğitiminde (Mitchell, Oslin \& Griffin, 2013) ve antrenörlük çalışmalarında kullanılmış olsa da (Charlesworth, 1993) sistematik olarak kavramsallaştırılmamıştır. Bu model ise durumsal oyun senaryolarını gerçek maçta yaşananların bir yansıması olarak kullanarak öğretimin kavramsal öğesi yapmaktadır. Aşağıda ortaokul beden eğitimi dersi futbol ve badminton öğretiminde kullanılan durumsal oyun senaryosu örnekleri paylaşıımıştır.

Şekil 1. Futbol Öğretiminde Örnek Durumsal Oyun Senaryosu

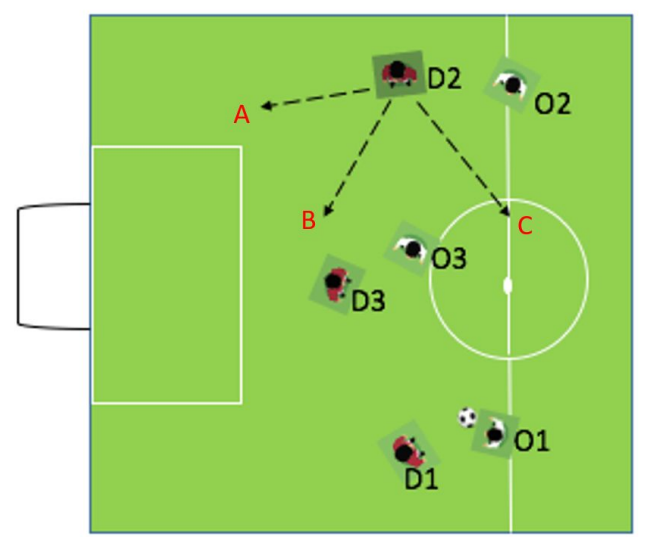

\section{İpucları}

1. Takımınız savunma yapıyor.

2. Hücum oyuncusu $\mathbf{O} \mathbf{1}$ topun sahibi.

3. Hücum oyuncusu $\mathbf{O 2}$ orta sahanın diğer tarafında savunma oyuncusu D2'ye yakın.

4. Hücum oyuncusu $\mathbf{O}_{3}$ orta sahanın merkezinde $\mathbf{D}_{\mathbf{3}}$ 'e yakın.

5. Savunma oyuncuları D1 ve D3 alan daraltmak için öne doğru hareket etmiş.

Eğer savunma oyuncusu D2 siz olsaydınız, o an bulunmanız gereken en doğru pozisyon ne olurdu?

A - Kaleye yakınlaşmak amacıyla geriye ceza sahasına doğru derinliğine bir koşu yaparım.

B - O3 topu aldığında onu savunmak için D3'e yaklaşırım.

C - Oz'ye atılabilecek potansiyel bir pası engellemek için öne içeri doğru hareketlenirim.

Bu cevabı neden tercih ettiğini kısaca açıklar mısın?

Ipuçlarının kavranması, ilişkisel analiz ve karar verme. Bu bileşen öğrencilerin uygun ipuçlarını algılaması, bunları oyunla ilişkilendirmesi ve nihayetinde eleştirel düşünebilme becerilerinin ortaya çıkarılması konusunda anahtar bir rol üstlenmektedir. Bireyin spesifik bir oyun senaryosundaki uygun ipuçlarını kavrama ve ayırt edebilme becerisi olarak ifade edilmektedir (Kirk \& MacPhail, 2002). Oyun senaryolarındaki ipuçları, savunma ve hücum oyuncularının pozisyonları, zayıf ve güçlü yanları, hareket örüntüleri, yönleri, iletişim için kullandıkları vücut dili de dahil olmak üzere oyunla ilişkili tüm parametreleri kapsar. Ilişskisel analiz ise öğrencinin bir oyun senaryosundaki ipuçları ve aralarındaki 
ilişkileri uygun ve akıcı bir şekilde belirleyebilme becerisi olarak ifade edilebilir. İpuçlarının kavranması ve bunlar arasındaki ilişkilerin analiz edilmesine bağlı olarak öğrenciler önceden belirlenmiş maç koşullarında uygun teknik, strateji ve taktiği seçerek karar verirler. İpuçlarını kavrama ve ilişkisel analiz pratiği yapan öğrenciler algısal ve analitik düşünme becerilerini geliştirme fırsatı bulurlar. Bu sayede her uygulama sonrası önceden belirlenmiş maç koşullarında uygun karar verebilme becerilerini biraz daha geliştirirler. Oyun Senaryolarıyla Durumsal Öğretim Modelinde öncelikle durumsal oyun senaryosu sunulur. Bu esnada öğrenciler, durumsal oyun senaryosuna yerleştirilmiş problemi tanımlar, uygun ipuçlarını algılar ve ipuçları arasındaki ilişkileri belirlemek için analiz yaparlar. Önceki öğrenmeler ve bilişsel algı kapasitelerine bağlı olarak, aynı oyun senaryosuyla karşı karşıya kalmalarına rağmen öğrenciler farklı ipuçlarını kavrayabilirler. Buna bağlı olarak yaptıkları ilişkisel analizler birbirlerinden farklıık gösterebilir. Ayrıca, öğrencilerin ipuçlarını kavrama ve ilişkisel analiz konusundaki hız ve doğrulukları farklıık gösterebilir. Burada dikkate alınması gereken nokta öğrencilerin önceki öğrenmeleri ve okul dışı deneyimlerinin ipuçlarını kavrama ve ilişkisel analizin hızı ve doğruluğu konusunda kritik bir rol üstlenmesidir. Oyun senaryoları daha karmaşık hale geldikçe ipuçlarını kavrama ve ilişkisel analiz hızı ve doğruluğu bakımından öğrenciler arasında farklılklar artar (Li, Xie \& Li, 2018).

Şekil 2. Badminton Öğretiminde Örnek Durumsal Oyun Senaryosu

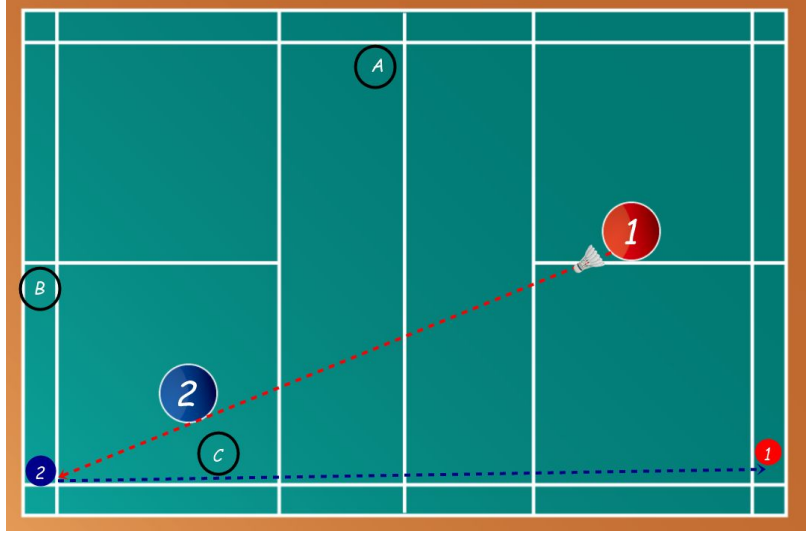

\section{İpuçları}

1. 1 numaralı oyuncu forehand yüksek servisi arka köşeye gönderiliyor.

2. 1 numaralı oyuncu servis sonrası sahanın merkezine geliyor.

3. 2 numaralı oyuncu gelen servisi forehand paralel clear ile karşılıyor.

4. Paralel clear vuruşu sonrası 2 numaralı oyuncu yerinde kalıyor.

5. Her iki oyuncu da sağ elini kullanıyor.

Eğer 1 numaralı oyuncu siz olsaydınız, 2 numaralı oyuncunun clear vuruşunu nasıl karşılardınız?

A - C bölgesine smaç vururum

B - A bölgesine çapraz drop atarım.

C - B bölgesine clear atar sonraki olası vuruşu karşılamak için sahanın merkezine geçerim.

Bu cevabı neden tercih ettiğini kısaca açıklar mısın?

Görüldüğü gibi futbol ve badminton örnek oyun senaryolarında öğrencilere çeşitli alternatif çözümler sunulmuştur. Öğrenciler, ünite boyunca beceri kalitelerini arttırıp, vurgulanan taktik ve teknikler arasındaki bağlantıları daha açık şekilde kavramaya başladıkça ve oyunun diğer öğeleri arasında iliş̧kisel analiz becerilerini geliştirdikçe sunulan alternatif çözümler azaltılabilir hatta kullanılmayabilir. Böylece durumsal oyun senaryoları adım adım daha karmaşık hale getirilmiş olur.

Durumsal oyun senaryosunun uygulanması. Durumsal oyun senaryosunun uygulanması oyuncuların aldıkları kararı hayata geçirmesi olarak tanımlanabilir. İpuçlarının kavranması, ilişkisel analiz ve karar verme sonrası, oyuncular karşılaştıkları problemleri çözmek için kendi eylem planlarını uygularlar. Oyuncular farklı çözüm yollarını denemek ve bunların etkili olup olmadığını test etmek konusunda cesaretlendirilirler. Bunun yanında, takım arkadaşlarının uygulamalarını gözlemlemeleri ve kendi 
uygulamaları üzerinde eleştirel bir bakış açısıyla yansıtma (derinlemesini düşünme) yapmaları konusunda oyuncular teşvik edilir. Denenen bir strateji beklendiği şekilde işe yaramadığında, oyuncular ipuçlarını yeniden inceleyip farklı bir ilişkisel analiz yapabilirler. Böylelikle, oyunculara aktif bir şekilde problem çözme, yansıtma yapma ve takım arkadaşlarından öğrenmeleri konusunda fırsat verilmiş olur. Bu sürecin en önemli katkısı oyuncuların aldığı kararlardan hangilerinin işe yarayıp yaramadığını kendi deneyimleri sonrası keşfetmeleridir.

Şekil 3. Oyun Senaryolarıyla Durumsal Öğretim Modeli Kavramsal Modeli (Li, Xi \& Li, 2018, s.357)

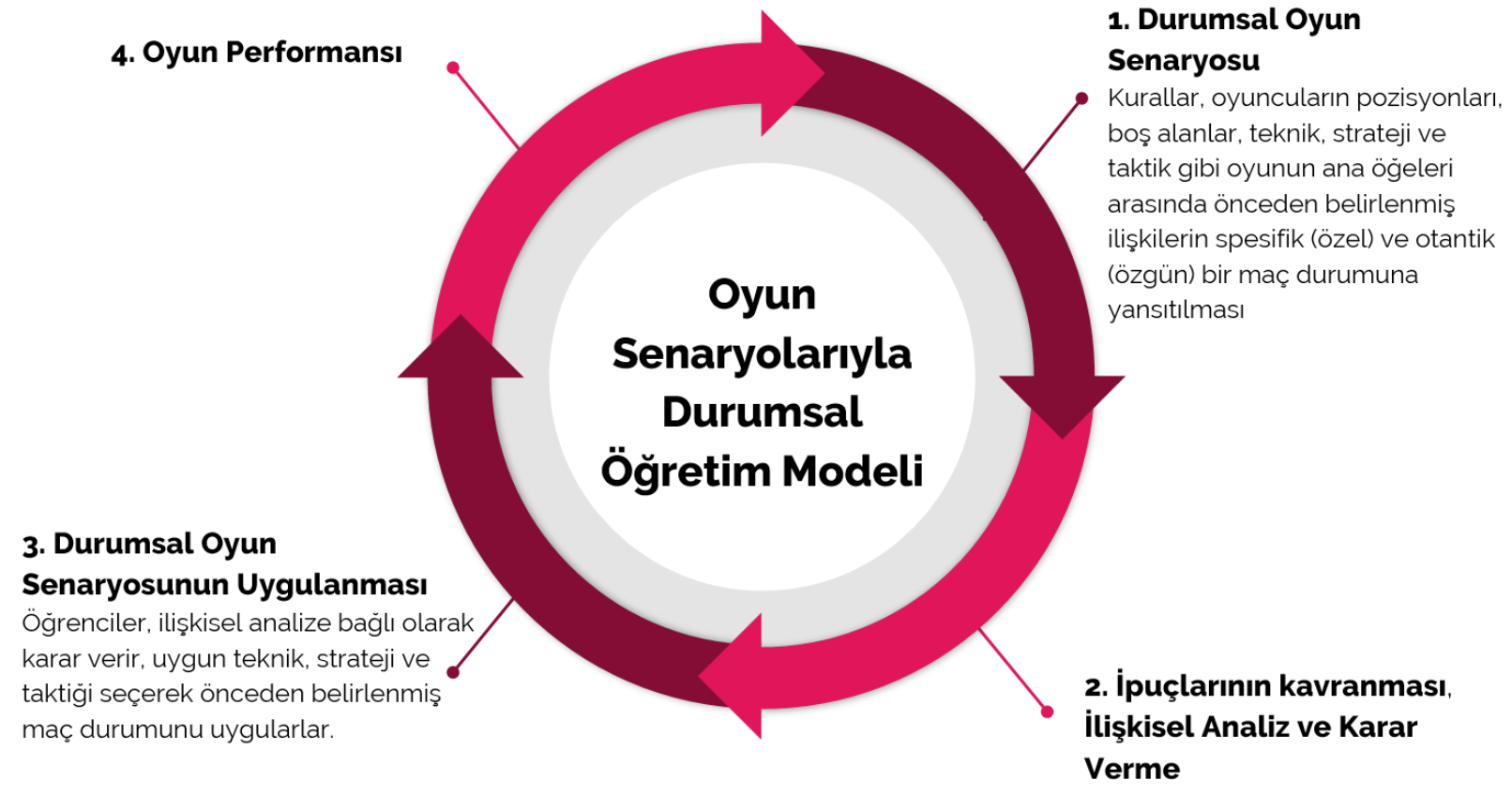

Oyun performansı. Oyun performansı bireyin özgün bir maç durumunda başarılı şekilde performans sergilemesi olarak tanımlanabilir. Durumsal oyun senaryoları farklı teknik, strateji ve taktikleri içeren gerçek maç koşullarının bir grup öğrenciye özel olarak yansııılması ve sunumu olarak kabul edilmektedir. Öğrenciler oyun senaryosunda beklenen performansı ortaya koyamazsa öğretmen önceki oyun senaryosunu yeniden yapılandırmak için çeşitli uyarlamalar yapabilir. Öğrencilerin oyun senaryosunu başarılı bir şekilde uygulaması durumunda ise öğretmen daha kapsamlı ve karmaşık oyun senaryolarını sunar. Beden eğitimi öğretmeni ipuçlarının sayısını arttırarak ya da azaltarak da oyun senaryosunun zorluk düzeyini değiştirebilir. Oyun oynarken, öğrenciler önceki oyun senaryolarının çeşitli uyarlamalarıyla karşı karşıya kalabilirler.

\section{Modelin Anahtar Özellikleri}

Oyun Senaryolarıyla Durumsal Öğretim Modeli yedi adet anahtar özellik taşımaktadır: (1) analiz birimi, (2) ilişsisel, (3) durumsal ve spesifik, (4) otantik, (5) bilişsel ve problem çözme, (6) gelişim düzeyine uygun ve (7) güdüleyici. Bu bölümde yedi adet anahtar özellikle ilgili detaylar sunulmuştur.

Analiz birimi. Oyun Senaryolarıyla Durumsal Öğretim Modelinde durumsal oyun senaryoları öğrenciler, aktivite ve çevre arasındaki ilişkileri yansıtan analiz birimini oluşturur. Bu üç öğede 
yapılacak herhangi bir değişiklik, ilişkilerin farklılaşmasına dolayısıyla durumsal oyun senaryoları ile ilgili farklı kararlar ve uygulamaların oluşmasına neden olur.

ilişskisel. Oyun Senaryolarıyla Durumsal Öğretim Modeli öğretim içeriklerini ilişkisel bir bakış açısıyla ele alır. iliş̧kisel ifadesi ile vurgulanmaya çalışılan şey öğrenciler, öğretim tasarımları ve çevrenin hem birbirinden bağımsız hem de ilişkili olmasıdır (Rovegno, 2006). Her bir oyun senaryosu öğrenciler, aktivite ve çevre arasındaki ilişkinin belirlenmesi ile uygulanır. Örneğin; bir öğrencinin kendisine atılan pası alabilmesi (1) topu karşılamak için doğru alana hareketlenmesine, (2) pası atan takım arkadaşının doğru şekilde (hız, şiddet ve akıcılık) pası atabilmesine, (3) rakibin uyguladığı savunmanın şiddetine, (4) topun rengi ya da ağırlığına ve (5) pası veren ve karşılayan oyuncular arasındaki iletişim ve ilişkiye bağlıdır (MacPhail, Kirk \& Griffin, 2008). Başka bir ifadeyle öğrencinin topu karşılayabilmesi sadece oyuncunun kontrol tekniğinin kalitesine değil aynı zamanda çevresel faktörlerle ilişkisine bağlıdır.

Durumsal ve spesifik. Özgünlük, oyun senaryolarında, öğrencilerin pozisyonları, güçlü ve zayıf yönleri ya da vurgulanan teknik ve taktikler gibi farklı ipuçlarını ifade eder. Öğretim tasarımlarında, gerçek yaşamdan soyutlanmış bilgiler yerine detaylı ilişkisel bilgiler ve spesifik ipuçlarının aktarılmasıyla, öğrencilerin öğretilen teknik ve taktiği anlamdırmaları ve başarıı şekilde uygulamalarına fırsat verilir. Örneğin; öğrencilere futbolda kenar ortaları öğretilirken ceza sahasında topla buluşması hedeflenen diğer oyuncunun konumu, sıçrama kapasitesi, kafa vuruşu becerisi ve rakiplerin konumu gibi önemli ipuçları aktarılır. Beceriyi gerçekleştirecek öğrenci, nereye ve nasıl orta yapması gerektiği konusundaki kararını bu ipuçlarına bağlı olarak verir.

Otantik. Otantiklik, öğretilecek konunun öğretilen sporun gerçek yaşamda oynandığı halini yansıtıyor olmasıyla ilgilidir. Bu bağlamda bu modeldeki tüm durumsal oyun senaryoları pratik, anlamlı ve gerçek yaşamla ilişkilidir (Rovegno, 2006). Bu modelin kullanılığı beden eğitimi derslerinde öğretilen konular gerçek yaşamdan alınmıştır. Durumsal oyun senaryolarında yer alan bilgiler, kullanılacakları sosyal bağlamda (gerçek maç koşulları) oluşturuldukları şekilde sunulur. Karar verme süreçleri herhangi bir spora ya da öğrencilerin gerçek yaşamlarındaki herhangi bir duruma aktarılabilir.

Bilişsel ve problem çözme. Tüm durumsal oyun senaryoları öğrencilere çözmeleri gereken problemler olarak sunulur (Li, Xie \& Li, 2018). Öğrenciler karar verme sürecinin tam merkezindedirler. Buna bağlı olarak ne yapacaklarına (taktiksel farkındalık), nasıl yapacaklarına (beceriyi gerçekleştirme), ne zaman yapacaklarına (zamanlama) ve nerede yapacaklarına (alan) kendileri karar verirler (Mitchell, Oslin \& Griffin, 2013). Beden eğitimi öğretmenleri öğrencilerin çözmesi için bir dizi ipucu içeren ve oyunla ilgili bir problemi yansıtan bir durum tasarlar. Öğrenciler bu durumu öğretilen sporun sosyal dinamiklerini de dikkate alarak çözmeye çalışırlar.

Gelişim düzeyine uygunluk. Gelişimsel uygunluk öğretilecek konunun (durumsal oyun senaryosu) öğrencilerin yaş, beceri ve bilişsel gelişim düzeylerine uygun olduğunu vurgulamaktadır. Öğretilen içerikler belirli bir yaşa özgü gerçek maç koşullarını yansıtır şekilde tasarlanmıştır. Örneğin, futbolda gelişim düzeyine uygun içerikleri oluşturabilmek adına her bir yaş için (8-14 yaş) rekreasyonel ve elit seviyede maçlar izledik. Ardından, belirlediğimiz teknik ve taktik becerileri antrenörler, oyuncular, beden eğitimi öğretmenleri ve öğretim görevlilerinden oluşan bir uzman grubu inceledi ve onayladı. Böylece, farklı yaş düzeylerine uygun teknik ve taktiklerin dahil edilmesiyle oluşturulan durumsal oyun senaryoları öğrenme görevi olarak öğrencilere sunuma hazır hale getirilmiş oldu (Li, Dervent \& Xie, 2018). Bu nedenle futbolda öğretilecek içeriklerin farklı yaş gruplarının bilişsel ve beceri gelişimlerini en iyi şekilde yansıttığı rahatlıkla söylenebilir. Badminton, voleybol, masa tenisi, basketbol öğretimi için de benzer çalışmalar halihazırda sürdürülmektedir. 
Güdüleyici. Yukarıda değinilen anahtar özelliklerinin tümü aslında bu modelin neden güdüleyici olduğunu göstermektedir. Öncelikle, otantik öğrenme uygulamaları öğrencileri öğrenme sürecinde aktif kılarak öğrenmeyi onlar için anlamlı hale getirmektedir. Öğrencilerin katıım ve bağlııkları arttıkça oyunlardaki beceri ve bilgileri de artar. Bu gelişim sonuç olarak oyuncuları öğrenme ortamına sürekli ve istekli katılım için güdüler. İkinci olarak, oyuncular takım içinde kimlik geliştirmeye başlarlar. Bu kimlik hem bilgi (doğru teknik ve taktiğin kullanıması) hem özdeğer (takımın bir parçası olmak) özellikleri taşır. Üçüncüsü, beden eğitimi öğretmenlerinin verdikleri pozitif geri bildirimler öğrencileri gelişimlerini fark etmelerini sağlayarak onları motive eder. Dördüncüsü, oyunculara gerçek yaşamdan aktarılarak sunulan olgun uygulamalar sürekli katıım konusunda güdüleyici rol üstlenirler. Son olarak, her bir oyun senaryosunda sunulan problem durumları oyuncuları birlikte ve aktif şekilde çalışmak için motive ederken aynı zamanda problemi çözmeye yönelik farklı yaklaşımlar üzerine eleştirel bir şekilde düşünme konusunda teşvik eder (Xie, 2018).

\section{Modelin Pedagojik Adımları}

Beden eğitimi öğretmenlerinin Oyun Senaryolarıyla Durumsal Öğretim Modelini başarılı şekilde uygulayabilmeleri için beş pedagojik adımı takip etmeleri gerekmektedir. Bu adımlar şu şekilde sıralanabilir (1) durumsal oyun senaryosunun sunumu, (2) ipuçlarının kavranması ve ilişkisel analiz, (3) öğretim ve gösterim, (4) öğrenciler durumsal oyun senaryosunu uygularken öğretmenin geri bildirim vermesi, (5) tartışma

1. Adım. Durumsal oyun senaryosunun sunumu. Bu ilk adımda beden eğitimi öğretmeni durumsal oyun senaryosunu grafik, video, resim gibi görsel materyaller ya da öğrencileri sahaya senaryoya uygun şekilde yerleştirerek sunar ve gösterir.

Şekil 4. Oyun Senaryolarıyla Durumsal Öğretim Modeli Pedagojik Adımları

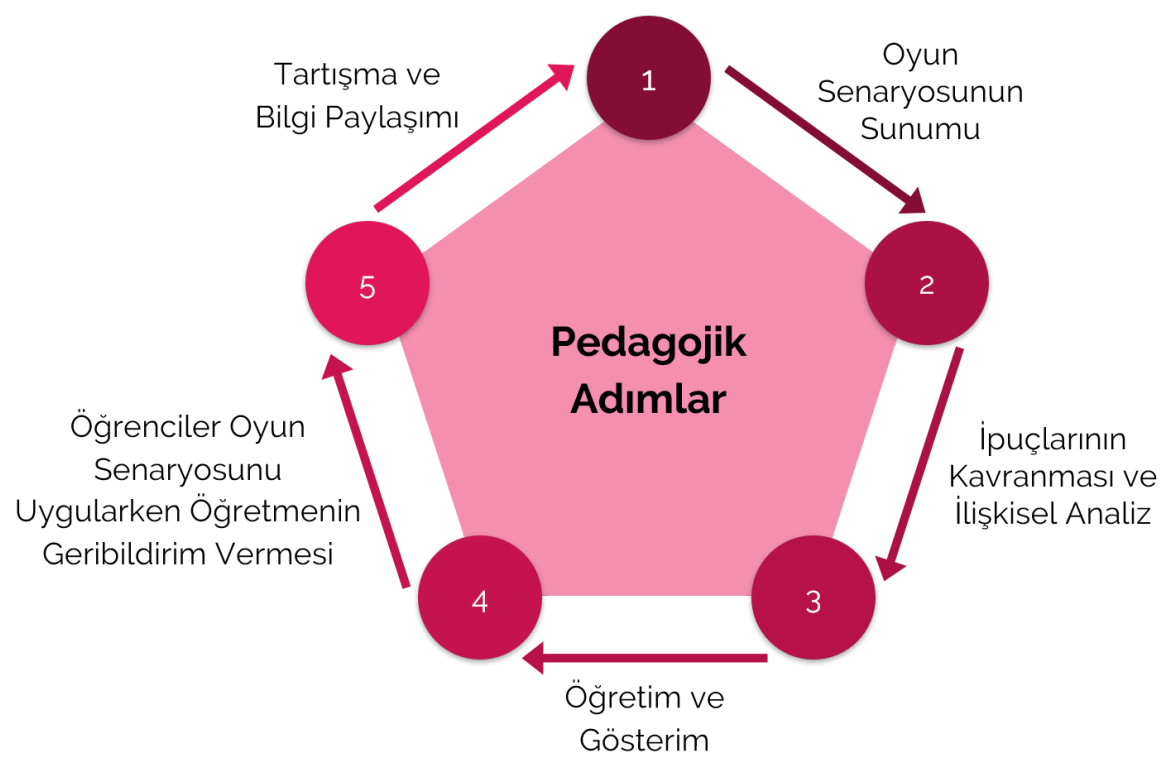

2. Adım. Ipuçlarının kavranması ve ilişkisel analiz. Beden eğitimi öğretmeni öğrencilerin doğru taktiksel kararları verebilmeleri için ipuçlarını belirlemeyi ve ilişkisel analiz yapabilmelerini destekleyen yönlendirici sorular sorar. Öğrencileri kendi takımları içinde tartışarak uygun çözüm yolunu geliştirmeye çalışılar. 'Kale nerede?', 'Top kimde?', Savunma ve hücum oyuncuları nerede?', 
'Bu durumda senden beklenen nedir?', 'Takım arkadaşların hangi teknikleri kullanmalı?', 'Takımınla hangi strateji/taktiği kullanmalısınız?' kullanılabilecek yönlendirici sorular için örnek olarak verilebilir.

3. Adım. Öğretim ve gösterim. Öğrenciler, beden eğitimi öğretmeninin rehberliğinde durumsal oyun senaryosu ile ilgili bir karara vardıklarında öğretmen öğrenme görevini içeren senaryonun gösterimini gerçekleştirir. Kullanılması istenen teknik ve taktiklerin kritik elemanları (anahtar noktalar) bu adımda öğrencilere sunulur.

4. Adım. Öğrenciler durumsal oyun senaryosunu uygularken öğretmenin geri bildirim vermesi. Her bir oyun senaryosunu uygulamak için oyunculara yeterli zaman tanınır. Öğrenciler uygulamayı gerçekleştirirken, öğretmen kullanılması istenen teknik ve taktiğe yönelik pozitif geri bildirimler verir. Geri bildirimler, oyuncuların oyun senaryosunu uyguladığı esnada farklı ipuçları arasındaki ilişkileri belirleme (savunma ve hücum oyuncularının pozisyonları, hücum yönü, pasın atılması gereken yer, yön vb.) ve bunları analiz etme konusunda destekleyici olmalı ve taktiksel karar verme süreçlerine odaklanmalıdır.

5. Adım. Tartışma. Beden eğitimi dersinin sonunda, öğretmen o derste öğretilen durumsal oyun senaryoları ile ilgili tartışma seansına rehberlik ederken oyuncuları aldıkları kararları ve uygulamaları sorgulama konusunda cesaretlendiren çeşitli yönlendirici sorular sorar. Örneğin; 'Aldığınız taktiksel kararlar oyun senaryosunu uygularken işinize yaradı mı?', Nasıl? Bize anlatır mısınız? (gösterir misiniz?) 'Sıradaki derste aldığınız kararda değişiklik yapmak ister misiniz? Neden?'. Tüm bu sorular öğrencilerin öğrendikleri konuya zihinsel olarak odaklanmaya, olası kararlar ve sonuçlar üzerine derinlemesine düşünmeye teşvik etmek için kullanılır.

\section{Tartışma ve Sonuç}

Oyun Senaryolarıyla Durumsal Öğretim Modeli beden eğitimine derslerinde spor dallarının öğretimine yönelik olarak sunulmuş yenilikçi bir pedagojik modeldir (Li, Xie \& Li, 2018). Bu çalışmanın amacı Türkiye beden eğitimi ve spor dersi öğretim programları eğitim felsefesiyle uyumlu bir teorik yapıya sahip Oyun Senaryolarıyla Durumsal Öğretim Modelinin bileşenleri, özellikleri ve pedagojik adımlarıyla ilgili detayları sunmaktır.

Oyun ve sporlar içeriğinde keyif almak ve sosyalleşmek için birçok fırsat barındırıyor olmasından dolayı beden eğitimi derslerinde öğrenciler tarafından diğer konulara oranla daha fazla tercih ediliyor olsalar da (Hastie \& Mesquita, 2016) çoğunlukla geleneksel ya da teknik odaklı yaklaşımlar temel alınarak öğretilmektedirler. Geleneksel yaklaşımı tercih eden beden eğitimi öğretmenleri genellikle öğrencilerine öğretilen tekniğin kritik elemanlarını anlatır ve gösterir. Ardından tam saha maç içeren öğretim tasarımıyla dersi tamamlar (Rovegno, 1995; Siedentop, 1994). Teknik odaklı yaklaşımda ise öğretmenler doğrudan öğretim modelini kullanarak spor dalına özgü teknik becerilerin gelişimine odaklanır (Rink, 1996). Bu yaklaşımda öğrencilerin oyun oynamaya başlamadan önce belirli düzeyde teknik beceriye sahip olması beklenir. Öğrencilerin oyun oynamayı başarabilmeleri ancak spor dalının tekniklerini yeterince pratik yapmalarıyla mümkündür. Bilişsel ve teknik gelişimi birbirinden ayrı ele alan teknik odaklı yaklaşım sporların öğretimini oynandığı çevreden soyutlamış olur (Siedentop, 1994).

Beden eğitimine özgü öğretim modellerini kullanan öğretmen sayısı göreceli olarak artıyor olsa da beden eğitimi öğretmenlerinin çoğunlukla geleneksel yaklaşımları tercih ettikleri görülmektedir. Rovegno (1995) sporların öğretiminde geleneksel yaklaşımların bu denli tercih ediliyor olmasının geçmiş oyunculuk deneyimleri ve yetersiz alan bilgisi olabileceğini belirtmişstir. Oyun temelli öğretim için beden eğitimi öğretmenlerinin intiyaç duyduğu iki tür alan bilgisi vardır; genel alan bilgisi (GAB) ve 
özelleşmiş alan bilgisi (ÖAB). GAB oyun kuralları, görgü kuralları ve güvenlik kuralları bilgisi ile teknik (teniste forehand vuruş, basketbolda gögüs pas) ve taktik (voleybolda dublaj, hentbolda fast-break) bilgisini içerir (Ward, 2009). Sadece oyun kuralları ve tekniklere odaklanan öğretim, becerikli oyun performansı için gerekli diğer öğeleri göz ardı ettiğinden dolayı etkili öğrenme fırsatı yaratma konusunda sınırlıdır (Harvey \& van der Mars, 2010). Beden eğitimi öğretmenlerinin birçoğu öğrettikleri farklı oyunlar ve sporlara özgü kurallar ve teknikleri bilir. Ancak becerikli oyun performansı için gerekli taktik ve stratejileri ne kadar iyi öğretebilecekleri net değildir (Ward \& Ayvazo, 2016; Ward, Piltz \& Lehwald, 2018). ÖAB ise teknik ve taktiklerin küçük adımlardan oluşan öğretim tasarımlarını ve bunların öğrencilere sunumunu içerir. Öğrencilerin öğretilen teknik ve taktikleri uygularken takımca ya da bireysel olarak yaptıkları hatalarının tespit edilmesi de ÖAB kapsamındadır (Ward, 2009). Beden eğitimi öğretimi için GAB ve ÖAB gerekliliği. SHAPE America (2014) beden eğitimi öğretmen yetiştirme programları ulusal standartlarının ilkinde öğretmenlerin bilmesi ve uygulaması gereken bilgiler içinde de vurgulanmaktadır. Beden eğitimine özgü öğretim modellerini etkili şekilde öğretebilmek için öğretmenlerin GAB dışında küçük adımlarla basamaklayarak öğretim tasarımı geliştirme becerisini ortaya koyan AÖB ve öğretim içeriğini öğrenciler için anlaşılabilir ve uygulanabilir düzeye uyarlamak için öğretmenin aldığı kararları içeren pedagojik alan bilgisine derinlemesine sahip olması gerekir (Ayvazo, 2007; Ward \& Ayvazo, 2016).

Beden eğitimi öğretiminin model temelli bir yaklaşımla ele alınması öğrencilerin öğrendikleri bilgi ve becerileri farklı ortamlara aktarabilme konusunda önemli fırsatlar sunar (Metzler, 2011). Beden eğitimine özgü öğretim modellerinin ortak noktası teknik ve taktiksel karar verme becerilerini uyarlanmış oyunlarla öğretiyor olmasıdır. Oyunlardaki uyarlamalar oyuncu sayıları, hücum-savunma oyuncularının oranları, kurallar, kullanılan ekipmanlardaki değişikliklerle sağlanabilir (Launder \& Piltz, 2013). Oyun Senaryolarıyla Durumsal Öğretim Modelinde öğrenciler taklit ederek öğrenen pasif bireyler değil aksine kendi taktiksel kararlarını veren ve çözüm yollarını uygulayan zihinsel olarak aktif bireylerdir. Beden eğitimi öğretmeni, ipuçları ve yönlendirici sorularla öğrencilerini cesur kararlar alma konusunda destekler. Bu yönüyle beden eğitimi öğretmeni öğrencileri için kolaylaştırıcı olmanın yanında zorlu görevlerin üstesinden gelmeleri, karmaşık görevleri öğrenebilmeleri için öğrencilerini meydan okumaya davet eder.

Oyun Senaryolarıyla Durumsal Öğretim Modelinin Türkiye'deki beden eğitimi ve spor dersi öğretim programlarının vurguladığı becerilerin geliştirilmesi için beden eğitimi öğretmenlerinin kullanabileceği işlevsel bir eğitsel araç olabileceği düşünülmektedir. Şöyle ki 5-8. sınıflar beden eğitimi ve spor dersi öğretim programı hareket strateji ve taktikleri alt öğrenme alanında yer alan kazanımlar öğrencilerin bireysel ve grupla problem çözme becerilerine ve problemler karşısında aldıkları taktiksel kararları uygulamalarına atıfta bulunmaktadır (MEB, 2018). Beden eğitimi dersini Oyun Senaryolarıyla Durumsal Öğretim Modeliyle işleyen bir öğretmen, öğrencileri taktiksel karar verme süreçlerinde destekler, onların oyun senaryosundaki ipuçlarını belirlemeleri ve böylece ilişkisel analiz yapabilmeleri için öğrenmeyi zenginleştirici sorular sorar. Modelin sözü edilen pedagojik adımları beden eğitimi ve spor dersi programının ilkeleri ve kazanımlarıyla örtüşmektedir.

5-8. sınıflar beden eğitimi ve spor dersi programının ilkeleri incelendiğinde eleştirel ve yansıtıcı düşünmeyi ön plana aldığı görülmektedir. Programın BE.7.1.2.3. numaralı kazanımı "hazırlayıcı oyun ve etkinliklerde karşılaştığı problemlere grupla çözümler üretir" (MEB, 2018, s.22) olarak belirtilmiştir. Örneğin; modelin bileşenlerinden ipuçlarının kavranması, ilişkisel analiz ve karar verme aynı zamanda pedagojik adımlarından tartışma programın vurguladığı ilkelerin hayata geçirilmesi için uygulanabilir eğitsel bir yol olarak kullanılabilir. 
Oyun Senaryolarıyla Durumsal Öğretim Modelinin temel aldığı durumsal öğrenme kuramı bilginin oluşturulmasını ve öğrenmeyi yapılandırmacılık yaklaşımına dayanarak açıklamaya çalışmaktadır (Kirk \& MacDonald, 1998). Yapılandırmacı yaklaşım öğrenmeyi bireyin kendi bağlamındaki aktif anlam arayışı olarak nitelendirir. Öğrenmenin sosyal ve kültürel bağlamlarda bulunduğunu ve bu bağlamların öğrenmeyi etkilediğini öne sürer. 5-8. sınıflar beden eğitimi ve spor dersi öğretim programının 3. ilkesindeki "öğrenci merkezli ortamlarda, öğrencilerin kendi öğrenmelerini yapılandırmalarına imkân verir ve 8. ilkesindeki "öğrencilerin eğitiminde, çevresi ve diğer kişilerle deneyimleri önemlidir" ifadeleri incelendiğinde programın yapılandırmacı yaklaşıma uygun olarak hazırlandığı göze çarpmaktadır (MEB, 2018, s.10). Yapılandırmacı yaklaşım ayrıca öğrenmenin çok boyutlu olduğunu vurgular. Oyun Senaryolarıyla Durumsal Öğretim Modeli teknik ve taktikleri bir arada öğreterek öğrencilerin devinişsel, bilişsel ve duyuşsal kazanımlar elde edebilmesi için yapılandırmacı yaklaşımın bu vurgusunu kullanmaktadır. Dolayısıyla Oyun Senaryolarıyla Durumsal Öğretim Modelinin beden eğitimi ve spor dersi eğitim felsefesi, ilkeleri ve kazanımlarına uygun bir yapıya sahip olduğu buna yönelik eğitsel donanımlar içerdiği rahatlıkla söylenebilir. Türkiye'de eğitim programları yenilense de öğretmenlerin programların felsefe ve amaçlarını destekleyen uygulamaları derslerine aktaramadıkları görülmektedir (Akpınar \& Aydın, 2007; İnce \& Hünük, 2010). Bu modelin programın eğitim felsefesini kağıt üzerinden gerçek hayata aktarmakta beden eğitimi dersleri özelinde katkı sağlayabilecek bir pedagojik araç olabileceği düşünülmektedir.

Rovegno, Nevett, Brock ve Babiarz (2001) dördüncü sınıf öğrencilerinin basketbolda atma ve tutma becerilerini nası öğrendikleri ve beden eğitimi öğretmeninin sergilediği öğretimin öğrencilerin otantik ortamlarda taktik kullanımlarını nasıl etkilediğine yönelik bir çalışma yapmışlardır. Elde edilen bulgular öğrencilerin teknikleri farklı maç koşullarında kullanmakta zorlandıklarını ortaya koymaktadır. Çünkü; öğrenciler farklı maç koşullarının sosyal ve ilişkisel boyutunu tam olarak kavrayamamış, rakip ve kendi takım arkadaşlarının uzamsal konumları arasındaki ilişkileri analiz etmekte zorlanmışlardır. Öğrenciler bilgi düzeyinde taktikleri açıklayabilirken bunları farklı maç koşullarında uygulamaya aktarmakta zorluk çekmişlerdir. Bununla birlikte; Rovegno ve arkadaşları (2001) sunulan ipuçları üzerine aktif şekilde düşünmenin öğrencilerin daha olgun hareket becerileri sergilemelerine katkı sağladığını da belirtmişlerdir. Diğer bulgulardan biri de öğrenciler arasındaki sosyal ilişkilerin öğrencilerin bireysel performanslarını etkiliyor olmasıdır. Şöyle ki atılan hızlı ya da isabetsiz pas diğer öğrencinin tutma becerisini başarılı şekilde sergileyebilmesini etkiler. ilkkokul öğrencilerinin uyarlanmış oyunlarındaki temel becerileri üzerine yapılan bir başka çalışma da atma ve tutma becerilerinin durumsal, ilişkisel ve birbiriyle bağlantılı olması nedeniyle karmaşık dolayısıyla öğrenilmesinin zor olduğunu ortaya koymuştur (MacPhail, Kirk \& Griffin, 2008).

Başlangıç düzeyinde ve deneyimli tenisçilerin turnuvalardaki taktiksel karar verme ve beceri uygulama süreçlerini inceleyen araştırmalar genç ve deneyimsiz oyuncuların çoğunlukla kendi oyun stilleri ve özelliklerine odaklanarak karar aldıklarını ortaya koymaktadır (McPherson, 1999; 2000). Bu oyuncular çok nadir olarak rakibin güçlü ve zayıf yönlerini, oyun stillerini dikkate almışlar, maçın koşulları ile ilgili ilişkisel analiz yapmışlardır. Deneyimli oyuncular ise maç koşullarını, önceki vuruşları, rakip ve kendisinin bulunduğu pozisyonları dikkate alarak taktiksel kararlarını vermişler buna göre uygun beceriyi sergilemişlerdir. Maç boyunca rakibin güçlü, zayıf yönleri ve oyun stilleri ile ilgili analiz yapmayı sürdürmüşlerdir. Deneyimsiz ve deneyimli tenis oyuncuları arasındaki farkları ortaya koyan bu çalışmalar öğrencilere taktiksel karar verme becerilerinin sistematik olarak öğretilmesinin gerekli olduğu fikrini desteklemektedir. Bu bağlamda spor dallarına özgü teknik ve taktikleri birbirleriyle ilişkilendirerek bütüncül bir şekilde öğretilmesine dayanan Oyun Senaryolarıyla Durumsal Öğretim Modeli öğrencilerin maç koşullarındaki problem çözme ve karar verme becerilerinin geliştirilmesine katkı sağlar. Durumsal oyun senaryolarında sunulan ipuçlarını kavramak ve bunlar arasındaki ilişkileri 
analiz etmek için zihinsel çaba harcayan öğrenciler maç koşullarında uygun teknik, strateji ve taktiği seçerek yansıtıcı düşünme, karar verme ve problem çözme konusunda yetkinliklerini arttırabilirler.

Sonuç olarak; Türkiye beden eğitimi ve spor dersi öğretim programlarının eğitim felsefesi ve öğretim yaklaşımına uygun teorik yapısıyla Oyun Senaryolarıyla Durumsal Öğretim modelinin ülkemizde beden eğitimi ve spor derslerinde oyunlar ve sporların öğretilmesinde yenilikçi pedagojik bir model olarak etkili öğretim fırsatı oluşturabileceği düşünülmektedir. Kazanımları bilişsel, devinişsel ve duyuşsal tüm öğrenme alanlarını kapsayan bütüncül bir yaklaşımla ele alan bu modele yönelik çalışmaların gelecekte farklı oyun ve sporların öğretiminde öğrencilerin teknik gelişimi, taktiksel karar verme ve güdülenmeleri üzerindeki etkisini incelemesi önerilmektedir.

\section{Kaynakça}

Akpınar, B. \& Aydın, K. (2007). Change in education and teachers' perceptions of change. Education and Science, 32(144), 71-80.

Anderson, J. R., Lynne, M. R. \& Simon, H. A. (1996). Situated learning and education. Educational Researcher, 25(4), 5-11.

Ayvazo, S. (2007). Exploring the pedagogical content knowledge of effective teachers in physical education. Unpublished Doctoral Dissertation. The Ohio State University, Columbus, $\mathrm{OH}$, USA.

Bereiter, C. (1990). Aspects of an educational learning theory. Review of Educational Research, 60, 603-624. doi: 10.3102/00346543060004603

Bunker, D., \& Thorpe, R. (1982). A model for the teaching of games in secondary schools. Bulletin of physical education, 18(1), 5-8.

Charlesworth, R. (1993). Discussion topic- Designer games. Hockey Australia NCAS Course, Canberra, December.

Greeno, J. G., Smith, D. R., \& Moore, J. L (1992): Transfer of Situated Learning. D. Detterman \& R. I. Stemberg (Eds.), Transfer on trial: Intelligence, cognition, and instruction, 99-167.

Harvey, S. \& Van Der Mars, H. (2010). Teaching and assessing racquet games using play practice. Journal of Physical Education, Recreation \& Dance, 81(4), 26-54.

Harvey, S., Pill, S., \& Almond, L. (2018). Old wine in new bottles: A response to claim that teaching games for understanding was not developed as a theoretically based pedagogical framework. Physical Education and Sport Pedagogy, 23, 166-180. doi: 10.1080/ 17408989.2017.1359526

Hastie, P., \& Mesquita, I. (2016). Sport-based physical education. Routledge handbook of physical education pedagogies. London, UK: Routledge.

Hunuk, D., Ince, M. L., \& Tannehill, D. (2013). Developing teachers' health-related fitness knowledge through a community of practice: Impact on student learning. European Physical Education Review, 19(1), 3-20.

International Association for Physical Education in Higher Education [AIESEP] (2014). Position statement on physical education teacher education. Retrieved from http://aiesep.org/wp-content/ uploads/2014/11/2014-AIESEP-Position-Statement-on-Physical-Education-Teacher-Educ ation.pdf on January 2, 2019.

Ince, M.L. \& Hunuk, D. (2010). Experienced physical education teachers' use and perceptions of teaching styles during educational reform period. Education and Science, 35(157), 128-139. 
Kirk, D., Brooker, R. \& Braiuka, S. (2000). Teaching games for understanding: A situated perspective on student learning. Annual Meeting of the American Educational Research Association, New Orleans, LA.

Kirk, D. \& Kinchin, G. (2003). Situated learning as a theoretical framework for sport education. European Physical Education Review, 9, 221-235. doi: 10.1177/1356336X030093002

Kirk, D. \& Macdonald, D. (1998). Situated learning in physical education. Journal of Teaching in Physical Education, 17, 376-387. doi: 10. 1123/jtpe.17.3.376

Kirk, D. \& MacPhail, A. (2002). Teaching games for understanding and situated learning: Rethinking the Bunker-Thorpe model. Journal of Teaching in Physical Education, 21, 177-192. doi: 10.1123/jtpe.21.2.177

Launder, A. \& Piltz, W. (2013). Play practice: Engaging and developing skilled players from beginner to elite. Champaign, IL: Human Kinetics.

Lave, J. \& Wenger, E. (1991). Situated learning: Legitimate peripheral participation. New York, NY: Cambridge University Press.

Li, W., Dervent, F., \& Xie, X. (2018). Soccer Techniques and Tactics for Third-through Eighth-grade Students in Physical Education. Journal of Physical Education, Recreation \& Dance, 89(8), 23-28.

Li, W., Xie, X \& Li, H. (2018). Situated game teaching through set plays: A curricular model to teaching sports in physical education. Journal of Teaching in Physical Education, 37, 352-363. doi: 10.1123/jtpe.2018-0001

MacPhail, D., Kirk, D., \& Griffin, L. (2008). Throwing and catching as relational skills in game play: Situated learning in a modified game unit. Journal of Teaching in Physical Education, 27, 100-115. doi: 10.1123/jtpe.27.1.100

McLennan, N. \& Thompson, J. (2015). Quality Physical Education (QPE): Guidelines for Policy Makers. UNESCO Publishing.

McPherson, S. (1999). Expert-novice differences in performance skills and problem representations of youth and adults during tennis competition. Research Quarterly for Exercise and Sport, 70, 233-251. doi: 10.1080/02701367.1999.10608043

McPherson, S. (2000). Expert-novice differences in planning strategies during collegiate singles tennis competition. Journal of Sport and Exercise Psychology, 22, 39-62. doi: 10.1123/jsep.22.1.39.

Metzler, W. M. (2011). Instructional models for physical education. New York, NY: Routledge

Milli Eğitim Bakanlığı (MEB), (2018). 5-8. sınıflar beden eğitimi ve spor dersi öğretim programı. Ankara: Devlet Kitapları Müdürlüğü.

Mitchell, S., Oslin, J., \& Griffin, L. (2013). Teaching sport concepts and skills: A tactical games approach for ages 7 to 18. Champaign, IL: Human Kinetics.

Renshaw, I., Davids, K. \& Savelsbergh, G. (2010). Motor learning in practice: A constraints-led approach. London, UK: Routledge.

Rink, J. (1996). Effective instruction in physical education. Student learning in physical education: Applying research to enhance instruction, 171-198.

Rovegno, I. (1995). Theoretical perspectives on knowledge and learning and a student teacher's pedagogical content knowledge of dividing and sequencing subject matter. Journal of Teaching in Physical Education, 14(3), 284-304.

Rovegno, I. (2006). Situated perspectives on learning. In D. Kirk, D. Macdonald, \& M. O'sullivan (Eds.), The handbook of physical education (pp. 262-274). London, UK: Sage.

Rovegno, I., Nevett, M., Brock, S., \& Babiarz, M. (2001). Chapter 7: Teaching and learning basic invasion-game tactics in 4th grade: A descriptive study from situated and constraints theoretical perspectives. Journal of Teaching in Physical Education, 20(4), 370-388. 
Siedentop, D. (1994). Sport education: Quality PE through positive sport experiences. Human Kinetics Publishers.

Siedentop, D., Hastie, P. A., \& Van der Mars, H. (2011). Complete guide to sport education. Human Kinetics.

Society of Health and Physical Educators America, (SHAPE) (2014). National standards \& grade-level outcomes for $k-12$ physical education. Reston, VA: Human Kinetics.

United Nations Educational, Scientific, and Cultural Organization (UNESCO), (2015). Quality physical education: guidelines for policy makers. Paris: Author.

Ward, P. (2009) Content matters: Knowledge that alters teaching. Historic traditions and future directions of research on teaching and teacher education in physical education. In $L$. Housner, M. Metzler, P. Schempp and T. Templin. (pp. 345-356) Morgantown WV. Fitness Information Technology.

Ward, P. \& Ayvazo, S. (2016). Pedagogical Content Knowledge: Conceptions and findings in physical education. Journal of Teaching in Physical Education, 35(3), 194-207. Doi: 10.1123/jtpe.2016-0037

Ward, P., Piltz, W. \& Lehwald, H. (2018). Unpacking games teaching: What do teachers need to know? Journal of Physical Education, Recreation \& Dance, 89(4), 39-44.

Xie, X. (2018). Effects of situated game teaching through set plays on secondary students' tactical knowledge and situational interest in physical education. Unpublished doctoral dissertation. The Ohio State University, Columbus, OH, USA.

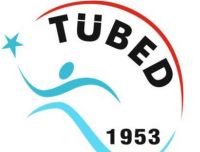

All rights reserved by Turkish Association of Physical Education Teachers. Tüm hakları Türkiye Beden Eğitimi Öğretmenleri Derneği'ne aittir. 